\title{
SUSTAINABILITY THROUGH BUSINESS MODEL AND SUPPLY CHAIN INNOVATION: AN EXPLORATORY STUDY ON INCLUSIVE BUSINESS MODELS IN TURKEY
}

\author{
Dicle YURDAKUL ${ }^{1}$
}

\begin{abstract}
Inclusive business, which is a concept that is attracting increasing attention, aims to provide goods, services or livelihoods in a scalable way by enabling people living at the bottom of the economic pyramid to take part in the value chain of the company's core business. This study aims to investigate private sector's level of engagement in inclusive business, the changes put forward in the supply chains of the companies which implemented these models and the relationship between inclusiveness and business model innovation. According to the results of the survey research, there is still a lack of interest and/or awareness regarding inclusive business among Turkish companies, particularly in terms of including the low income producers in the supply chain as suppliers. On the other hand, the research also shows that there is a strong relationship between supply chain innovativeness and inclusiveness, as well as company's future intentions to engage in inclusive business. Considering these findings, this study argues that developing the innovativeness capabilities of companies not only in terms of their products and services, but also their business models has the potential to increase companies' adoption of inclusive business.
\end{abstract}

Keywords: Inclusive Business, Innovativeness, Supply Chain, Supply Chain Innovation, Sustainability

JEL Classification: M10, M14, M31

\section{IŞ MODELI VE TEDARIK ZINCIRI YENILIKCÇiLIĞi ILE SÜRDÜRÜLEBILIIRLIK: TÜRKIYE'DE KAPSAYICI ISS MODELLERI ÜZERINE KEŞFEDICI BIR ARAŞTIRMA}

$\ddot{O} \mathbf{z}$

Giderek daha fazla ilgi çeken bir kavram olan kapsayıcı işletmeler, ekonomik piramidin en alt katmanında yer alan bireylerin, şirketin ana iş kolunun değer zincirinde görev alması yoluyla, onlara ölçeklenebilir bir şekilde mal, hizmet veya geçim kaynağı sağlamayı amaçlamaktadır. $\mathrm{Bu}$ çalışma, özel sektörün kapsayıcı işlere katılım düzeyini, bu modelleri uygulayan şirketlerin tedarik zincirlerinde ortaya konan değişiklikleri ve kapsayıcılık ile iş modeli inovasyonu arasındaki ilişkiyi incelemeyi amaçlamaktadır.Anket araştırmasının sonuçlarına göre, özellikle düşük gelirli üreticilerin tedarik zincirine dahil edilmesi açısından, Türk şirketleri arasında kapsayıcı faaliyetler konusunda halen ilgi ve/veya farkındalık eksikliği söz konusudur. Öte yandan, araşıırma aynı zamanda tedarik zinciri yenilikçiliği ile kapsayıcılık ve şirketin kapsayıcı bir işe girme konusundaki gelecek niyetleri arasında güçlü bir ilişki olduğunu göstermektedir.

$\mathrm{Bu}$ bulgular göz önüne alındığında bu çalışma, şirketlerin ürün ve hizmet yenilikçiliğinin yanı sıra iş modelli yenilikçiliği becerilerini de geliştirmelerinin kapsayıcı iş modellerini benimseme düzeylerini artırma potansiyeline sahip olduğunu öne sürmektedir.

1 Asst. Prof. Dicle Yurdakul, Altınbaş University, School of Business Administration, Department of Business Administration, Istanbul, Turkey, dicle.yurdakul@ altinbas.edu.tr. ORCID ID: 0000-0001-90268606 
Anahtar Kelimeler: Kapsayııı İşletmeler, Yenilikçilik, Tedarik Zinciri, Tedarik Zinciri Yenilikçiliği, Sürdürülebilirlik

JEL Sınıflaması: M10, M14, M31

\section{Introduction}

As the role of the private sector in development is increasing, it is becoming more and more important to reveal the necessary factors for fulfilling this role in a way that provides the highest benefit for both companies and the society. Although the debate about the role of companies in creating benefits is as old as the existence of companies, the perception of this role differs and brings in new discussions year by year with the increase in environmental and social problems.

There are different dimensions of these debates, starting from the impact on economic added value and job creation to the efforts to solve the social and environmental problems of the world. However, considering the changes in consumers' perception of "value creation" and the demands of governments from private sector to take a role of in solving the problems related to economic, environmental and social sustainability, it becomes inevitable that the companies take roles beyond creating economic value.

With this perspective, different terms and concepts are put forward with the influence of academia, development institutions, governments and the private sector. One of the important concepts put forward in this process is the concept of inclusive business which constitutes the main theme of this study. Inclusive enterprises are defined as those that provide goods, services or livelihoods in a scalable way by enabling people living at the bottom of the economic pyramid to take part in the value chain of the company's core business as suppliers, entrepreneurs, distributors, retailers or customers (G20 Inclusive Business Framework).

As of 2016, 10.9\% of the world's population lives below the 1.90 US \$ (purchasing power parity) level, which is considered to be the extreme poverty line. Ending poverty, which is one of the most fundamental problems related to economic and social sustainability, is the first of the 17 Sustainable Development Goals (SDG) set by the United Nations Development Program (UNDP) within the 2030 agenda. It is seen that these 17 goals, which have been agreed upon by the governments, development organizations, academia and civil society on a global scale, have been recognized and accepted by the private sector and many companies have integrated them into their sustainability strategies by focusing on some of these goals according to their fields of activity. At this point, inclusive business models emerge as a private sector approach that can make a significant contribution to the achievement of SDG\#1, "No Poverty".

With this approach in mind, this study aims to investigate private sector's level of engagement in inclusive business, the changes put forward in the supply chains of the companies which implemented these models and the relationship between supply chain innovation and inclusiveness. Accordingly, a comprehensive questionnaire was developed to understand the current level of supply chain inclusiveness and supply chain innovativeness of companies and the relationships between these variables and companies' intentions to engage in inclusive business.

Data received from 122 companies operating in various sectors in Turkey were included in the analysis. Findings, discussions and recommendations for action plans and policy development are presented in next chapters. 


\section{Literature Review}

Inclusive business approach focuses on finding permanent and sustainable solutions to poverty, which is one of its main objectives. On the other hand, inclusive business models target the main strategy of the company to ensure that goals related to profitability and social sustainability are met in tandem. In order to achieve this, traditional business models needs to be investigated with an innovative approach.

Integrating corporate social responsibility into the main strategy of the company is not only a necessity but also brings many advantages for the company's long-term success. Due to its positive effects on corporate reputation (Mitra, 2011; Zeng et al, 2013), consumer satisfaction and brand loyalty (Dragomir \& Anghel 2011; Martinez, Perez and del Bosque, 2013; Oberseder et al, 2013), employee morale (Wolf, 2013) and financial performance (Callan and Thomas, 2009; Chang and Kuo, 2008; Lin et al., 2011) corporate social responsibility significantly improves corporate sustainability.

Integrating individuals living at the bottom of the income pyramid into the supply chain in different roles such as consumer, supplier, entrepreneur, distributor and retailer, requires a shift from the traditional business models to an innovative, agile and inclusive approach. First of all, successful operations in and with the BOP markets requires a thorough understanding of the local markets' and customers' needs (Rangan et al., 2011; Weidner, Rosa and Viswanathan, 2010; Calton et al., 2013; Sharma and Lee 2012), how local capabilities interact with social context and technological applications (Dey et al., 2013); local adaptation in designing products (Viswanathan and Sridharan, 2012) and support of government regulations and trained staff who can make system adjustments (Berger and Nakata, 2013). In addition, it is important to evaluate the future of these initiatives in these markets, especially in terms of the scalability (Cooney and Shanks, 2010).

On the other hand, it is of great importance that these models be stakeholder-oriented in order to be successful (Kuzma and Kuzhabekova, 2011). The information obtained from the relationships established with different stakeholders increases the sustainable innovation capacity of companies and the effectiveness of corporate social responsibility activities (Fang, Huang and Huang, 2010). For example, consumers are encouraging companies to become socially responsible through both pressure (Lungu et al., 2014) and support. Corporate responsibility increases consumer satisfaction (Prud'homme and Raymond, 2013) and causes them to agree to pay higher prices for the products of socially responsible companies (Bask et al., 2013). On the other hand, the pressure of non-governmental organizations and changing expectations of the society also lead companies to integrate corporate social responsibility into their business models and supply chains (Mzembe and Meaton, 2014). In addition, taking the opinions of employees in these processes (Bolis, Brunoro and Sznelwar, 2014) and ensuring their actual involvement in the development and implementation stages (Metzner and Fischer, 2010) is very important for the success of these initiatives.

On the other hand, another factor that is emphasized in sustainability studies is the creation of a supportive and encouraging legal basis which is of great importance for the acceleration and continuity of these efforts. Governments and the business world need to set common goals and act together (VanSandt and Sud, 2012). 
On the other hand, long-term commitment of all stakeholders, including the members of the supply chain, is needed for sustainability-based business models to be successful. Since the expected outputs of these models will be realized in the long term, the level and duration of this commitment are among the most important factors affecting their success. Similarly, some studies suggest that engagement of internal stakeholders, i.e. senior management and employees, is more effective than external factors in the success of these business models (Duran-Encalada and Paucar-Caceres, 2012; Reiman et al., 2012; Hill and Rapp, 2014). In this context, building a supportive corporate culture is also critical.

Research suggesting collaborations between supply chain members argue that external governance should be applied through stakeholder collaboration to ensure the sustainability of the supply chain (Gimenez and Tachizawa 2012, Li et al., 2014). All members of the supply chain should cooperate and contribute in order to ensure that the profitability perspective is complemented with sustainable practices across the chain (Glover et al., 2014). Previous studies suggest the development of sustainable procurement and supply chains for inclusive businesses (Grob and Benn 2014) through supplier development efforts to improve capabilities (Lu, Lee and Cheng, 2012), increased collaboration and education of the suppliers, auditing, monitoring and measuring supplier performance (Morali and Searcy 2013). Furthermore, applying an innovative sustainable supply chain management (SSCM) perspective to BOP projects help multinational companies to achieve their sustainable development goals as it includes economic, social and environmental dimensions of sustainability (Gold, Hahn and Seuring, 2013). On the other hand, SSCM requires leadership support, expert know-how, internal procedural integration and close and intense supplier relationships (Spence and Bourlakis, 2009; Wolf, 2011; Lee et al., 2014; Varsei et al., 2014).

Considering these discussions, this study aims to investigate the role of private sector in social sustainability particularly through the level of engagement in inclusive business, the changes put forward in the supply chains of the companies which implemented these models and the relationship between supply chain innovation and inclusiveness.

\section{Methodology}

In accordance with the aim of the study, a quantitative research approach was adopted. A comprehensive questionnaire was developed for data collection which includes 7 point likert scale questions, open ended questions and multiple choice questions (41 substantive and 10 demographic questions) to understand the current level of supply chain inclusiveness and supply chain innovativeness of companies and the relationships between these variables and companies' intentions to engage in inclusive business. Main variables measured through the questionnaire include supply chain inclusiveness, future intention for inclusiveness, supply chain innovativeness and finally, company characteristics.

A link to a self-administered online survey was sent by email to senior executives of companies from different sectors, including SMEs, large national companies, multinational companies and social enterprises.

Following data collection, data cleansing was run through consistency checks (identifying out of range, inconsistent or extreme values) and treatment of missing responses. Variable respecification and scale transformation were done when needed. 
After data screening and cleansing, 122 completed surveys were used for further analysis. Data analysis was conducted using the appropriate statistical techniques through SPSS software.

\section{Findings}

First, descriptive analysis was run to understand the current situation among Turkish companies in terms of supply chain inclusiveness. As shown in Table 1, the mean scores for supply chain inclusiveness were found to be low, with a mean score of 2,78 for doing business with the poor as suppliers in local operations and 3,21 for doing business with the poor in the distribution channel in local operations. The scores for international operations were slightly higher, with mean scores of 3,06 and 3,67 respectively. As discussed in the previous studies on sustainable development, it is not enough for companies to include low income people in their operations; but they also should invest in the skills development of the disadvantaged groups - regardless of the role they play in the value chain of the company - to create a long-term social impact. Therefore, companies were also asked about how much they invest in skill and knowledge development of the poor, beyond the legal and obligatory skills development programs and educations. The mean score of the participant companies in terms of investing in the skill and knowledge development of the poor as suppliers was found to be 3.74 , while the score for distribution channel members was 3,58.

Table 1. Supply Chain Inclusiveness

\begin{tabular}{|l|l|l|}
\hline Item & Mean & $\begin{array}{l}\text { Std. } \\
\text { Deviation }\end{array}$ \\
\hline $\begin{array}{l}\text { Supply Chain Inclusiveness_Doing business with the poor as } \\
\text { suppliers (for example, buying products and/or services from } \\
\text { low income producers) in local operations }\end{array}$ & 2,78 & 1,638 \\
\hline $\begin{array}{l}\text { Supply Chain Inclusiveness_Doing business with the poor in } \\
\text { the distribution channel (as carriers, retailers etc.) in local } \\
\text { operations }\end{array}$ & 3,21 & 1,949 \\
\hline $\begin{array}{l}\text { International Supply Chain Inclusiveness_Doing business } \\
\text { with the poor as suppliers (for example, buying products } \\
\text { and/or services from low income producers) in international } \\
\text { operations }\end{array}$ & 3,06 & 2,069 \\
\hline $\begin{array}{l}\text { International Supply Chain Inclusiveness_Doing business } \\
\text { with the poor in the distribution channel (as carriers, retailers } \\
\text { etc.) in international operations }\end{array}$ & 3,67 & 2,280 \\
\hline $\begin{array}{l}\text { Investing in skill and knowledge development of the poor as } \\
\text { suppliers }\end{array}$ & 3,74 & 1,508 \\
\hline $\begin{array}{l}\text { Investing in skill and knowledge development of the poor as } \\
\text { distribution channel members }\end{array}$ & 3,58 \\
\hline
\end{tabular}


As discussed in the literature, inclusiveness in the business model requires companies to alter their current ways of doing business in significant ways.

This requires a perspective shift, which is often accompanied by the level of innovativeness, and being open to innovation in terms of the changes in the business model. Considering this, companies were asked to rate their level of innovativeness in terms of their supply chain operations. As shown in Table 2, participant companies' scores for supply chain innovativeness were also low. The highest mean value, 3,08 belongs to the item related to adapting company's offerings of products and services according to the needs of the poor (consumers). On the other hand, mean scores for the two items that are critical for supply chain inclusiveness, namely Item 3: Changed your distribution of products and services to do business with the poor and Item 4: Made changes in the development, production and distribution of your products in order to do business with the poor, were relatively lower, 2,72 and 2,83 respectively.

Table 2. Supply Chain Innovativeness

\begin{tabular}{|l|l|l|}
\hline Item & Mean & Std. Dev. \\
\hline $\begin{array}{l}\text { Adapted your firm's offerings of products and services } \\
\text { according to the needs of the poor }\end{array}$ & 3,08 & 1,577 \\
\hline $\begin{array}{l}\text { Made changes in your target market segment to target poor } \\
\text { consumers }\end{array}$ & 2,83 & 1,609 \\
\hline $\begin{array}{l}\text { Changed your distribution of products and services to do } \\
\text { business with the poor }\end{array}$ & 2,72 & 1,558 \\
\hline $\begin{array}{l}\text { Made changes in the development, production and distribution } \\
\text { of your products in order to do business with the poor }\end{array}$ & 2,83 & 1,609 \\
\hline $\begin{array}{l}\text { Developed new capabilities that are critical to gaining } \\
\text { competitive advantage through doing business with the poor }\end{array}$ & 3,02 & 1,618 \\
\hline $\begin{array}{l}\text { Formed any new forms of partnerships with other industry } \\
\text { actors to do business with the poor }\end{array}$ & 2,30 & 1,411 \\
\hline
\end{tabular}

Considering the low scores for supply chain inclusiveness and innovativeness of the participant companies, it is important to investigate the inclusiveness levels of the members of the supply chain that the company is working with. Interestingly, participants indicate that the companies in their supply chain do better in terms of level of inclusiveness. Participant companies reveal that their supply chain members include poor people in their business models $(5,51)$ and that these businesses are operating successfully $(5,34)$. According to these findings, participants think that the companies in their supply chains perform better than they do, in terms inclusiveness. 
Table 3. Supply Chain's Inclusiveness

\begin{tabular}{|l|l|l|}
\hline Item & Mean & Std. Dev. \\
\hline $\begin{array}{l}\text { Companies in our supply chain include poor people in their } \\
\text { business models }\end{array}$ & 5,51 & 2,982 \\
\hline $\begin{array}{l}\text { Companies in our supply chain are successful in their } \\
\text { businesses which include poor people. }\end{array}$ & 5,34 & 3,006 \\
\hline $\begin{array}{l}\text { Companies in our supply chain support our inclusive } \\
\text { operations }\end{array}$ & 4,27 & 1,816 \\
\hline
\end{tabular}

Having discussed the importance of companies' level of innovativeness in terms of adapting and changing their business models, this exploratory research also aimed to investigate the relationship between supply chain innovativeness and engagement in inclusive business and other forms of strategic corporate social responsibility. The results of the Pearson Correlation analysis reveal a strong relationship between supply chain innovativeness and international inclusiveness ( $r=, 654 \mathrm{p}=0,01)$, as well as company's future intentions to engage in inclusive business $(\mathrm{r}=, 678 \mathrm{p}=0,01)$. On the other hand, the relationship between supply chain innovativeness and inclusiveness in local operations $(r=, 391 \mathrm{p}=0,01)$ and strategic corporate social responsibility $(\mathrm{r}=, 328 \mathrm{p}=0,05)$ was found to be moderately strong.

Table 4. Correlations-Supply Chain Innovativeness

\begin{tabular}{|l|l|l|}
\hline Variable & $\begin{array}{l}\text { Pearson } \\
\text { Correlation } \\
\text { Coefficient }\end{array}$ & $\begin{array}{l}\text { Sig. } \\
\text { tailed) }\end{array}$ \\
\hline Inclusiveness &, $391^{* *}$ & 0,01 \\
\hline International Inclusiveness &, $654^{* *}$ & 0,01 \\
\hline Future Intention for Inclusiveness &, $678^{* *}$ & 0,01 \\
\hline Engaging in Strategic Corporate Social Responsibility & $.328^{*}$ & 0,05 \\
\hline
\end{tabular}

*Correlation is significant at the 0.05 level (2-tailed).

**Correlation is significant at the 0.01 level (2-tailed).

\section{Discussion}

Inclusive business is a relatively new concept in the development discussions, yet, its importance is increasing tremendously due to the interest of private sector to these business models which propose opportunities for profitability and social impact at the same time. Considering that the literature hosts limited discussions on the topic, this exploratory study aimed to contribute to the field through an investigation on inclusiveness in supply chains, particularly through an understanding on business model and supply chain innovativeness. 
As revealed by participant companies' low levels of supply chain inclusiveness, it can be argued that there is still a lack of interest and/or awareness regarding inclusive business among Turkish companies, particularly in terms of including the low income producers in the supply chain as suppliers. Lack of awareness regarding successful examples of inclusive business -both in terms of profitability and social impact- appears as a barrier in the way to improving the inclusiveness levels of companies, which shows the importance of knowledge and know-how sharing and showcasing best practices. On the other hand, the local supply chain inclusiveness scores were lower compared to international operations. A possible explanation might be the differences between countries in legal requirements, yet, this point needs further elaboration to clarify the reasons of this difference between the local and international operations. Companies' answers also reveal that skills development efforts were also lower than the scale average, which points out the need to increase awareness among companies about the importance of investing in skills and knowledge development for the mutual benefit of the supply chain member and the company (Lu, Lee and Cheng, 2012).

On the other hand, findings of this study reveals that participant companies think the companies in their supply chains perform better than they do, in terms of their level of inclusiveness, and that they are successful in these inclusive businesses. Furthermore, they also point out the fact that the companies in their supply chains support their inclusive operations, with a mean score of 4,27 . This finding brings in the discussion that a collective approach towards inclusiveness and social sustainability can increase the social impact created through these initiatives. Extant research points out to the importance of collaboration particularly in the BoP markets. Partnerships help adapting to the subsistence marketplace-specific dynamics, and partners from multiple sectors may help in addressing the problem of institutional gaps in these markets (Rivera-Santos, Rufin and Kolk 2012). Consequently, establishing partnerships and ensuring goal alignment within the supply chain may help in scaling up the impact created by inclusive operations.

Finally, this study aimed to bring up the discussion about the importance of innovativeness in building inclusive operations. Inclusive business approach requires companies to investigate their business models with a critical and innovative perspective in order to change these models to become more inclusive in various dimensions. The findings of this research also supports this hypothesis through the strong relationship found between supply chain innovativeness and international inclusiveness, as well as company's future intentions to engage in inclusive business. Consequently, it is possible to argue that developing the innovativeness capabilities of companies not only in terms of their products and services, but also their business models has the potential to increase companies' adoption of inclusive business.

\section{References}

Bask, A., Halme, M., Kallio, M., \& Kuula, M. (2013). Consumer preferences for sustainability and their impact on supply chain management The case of mobile phones. International Journal of Physical Distribution \& Logistics Management, 43(5-6), 380-406.

Bolis, I., Brunoro, C. M., \& Sznelwar, L. I. (2014). Work in corporate sustainability policies: The contribution of ergonomics. Work-a Journal of Prevention Assessment \& Rehabilitation, 49(3), 417-431. 
Callan, S. J., \& Thomas, J. M. (2009). Corporate financial performance and Corporate Social Performance: An Update and Reinvestigation. Corporate Social Responsibility and Environmental Management, 16(2), 61-78.

Calton, J. M., Werhane, P. H., Hartman, L. P., \& Bevan, D. (2013). Building partnerships to create social and economic value at the base of the global development pyramid. Journal of Business Ethics, 117(4), 721-733.

Chang, D. S., \& Kuo, L. C. R. (2008). The effects of sustainable development on firms' financial performance - an empirical approach. Sustainable Development, 16(6), 365-380.

Cooney, K., \& Shanks, T. R. W. (2010). New approaches to old problems: market-based strategies for poverty alleviation. Social Service Review, 84(1), 29-55.

Dey, B. L., Binsardi, B., Prendergast, R., \& Saren, M. (2013). A qualitative enquiry into the appropriation of mobile telephony at the bottom of the pyramid. International Marketing Review, 30(4), 297-322.

Dragomir, V. D., \& Anghel, E. R. (2011). Social responsibility practices regarding facilities granted to employees and consumer protection in selected European companies. Amfiteatru Economic, 13(29), 86-103.

Duran-Encalada, J. A., \& Paucar-Caceres, A. (2012). A system dynamics sustainable business model for Petroleos Mexicanos (Pemex): case based on the Global Reporting Initiative. Journal of the Operational Research Society, 63(8), 1065-1078.

Fang, S. R., Huang, C. Y., \& Huang, S. W. L. (2010). Corporate social responsibility strategies, dynamic capability and organizational performance: Cases of top Taiwan-selected benchmark enterprises. African Journal of Business Management, 4(1), 120-132.

Gimenez, C., \& Tachizawa, E. M. (2012). Extending sustainability to suppliers: a systematic literature review. Supply Chain Management-an International Journal, 17(5), 531543.

Glover, J. L., Champion, D., Daniels, K. J., \& Dainty, A. J. D. (2014). An institutional theory perspective on sustainable practices across the dairy supply chain. International Journal of Production Economics, 152, 102-111.

Gold, S., Hahn, R., \& Seuring, S. (2013). Sustainable supply chain management in "Base of the Pyramid" food projects-A path to triple bottom line approaches for multinationals? International Business Review, 22(5), 784-799.

Grob, S., \& Benn, S. (2014). Conceptualising the adoption of sustainable procurement: an institutional theory perspective. Australasian Journal of Environmental Management, 21(1), 11-21.

Hill, R. P., \& Rapp, J. M. (2014). Codes of ethical conduct: A bottom-up approach. Journal of Business Ethics, 123(4), 621-630.

Kuzma, J., \& Kuzhabekova, A. (2011). Corporate social responsibility for nanotechnology oversight. Medicine Health Care and Philosophy, 14(4), 407-419.

Lee, D., Moon, J., Cho, J., Kang, H. G., \& Jeong, J. (2014). From corporate social responsibility to creating shared value with suppliers through mutual firm foundation in the Korean bakery industry: a case study of the SPC Group. Asia Pacific Business Review, 20(3), 461-483.

Li, Y. J., Zhao, X. K., Shi, D., \& Li, X. (2014). Governance of sustainable supply chains in the fast fashion industry. European Management Journal, 32(5), 823-836.

Lin, M. J., Lee, D. C., \& Lee, L. T. (2011). Using Tobin's Q ratio to testing the stakeholder theory applied to the corporate social performance. African Journal of Business Management, 5(34), 12951-12957.

Lu, R. X. A., Lee, P. K. C., \& Cheng, T. C. E. (2012). Socially responsible supplier development: Construct development and measurement validation. International Journal of Production Economics, 140(1), 160-167. 
Lungu, C. I., Dascalu, C., Caraiani, C., \& Balea, E. C. (2014). Econometric approach of the scenarios regarding the impact of the consumer's empowerment and companies' responsibility for environment sustainability on the electricity market performance. Amfiteatru Economic, 16(35), 187-200.

Martinez, P., Perez, A., \& del Bosque, I. R. (2013). Measuring corporate social responsibility in tourism: development and validation of an efficient measurement scale in the hospitality industry. Journal of Travel \& Tourism Marketing, 30(4), 365-385.

Metzner, R. J., \& Fischer, F. M. (2010). Fatigue and workability in Brazilian textile companies in different corporate social responsibility score groups. International Journal of Industrial Ergonomics, 40(3), 289-294.

Mitra, R. (2011). Framing the corporate responsibility-reputation linkage: The case of Tata Motors in India. Public Relations Review, 37(4), 392-398.

Morali, O., \& Searcy, C. (2013). A review of sustainable supply chain management practices in canada. Journal of Business Ethics, 117(3), 635-658.

Mzembe, A. N., \& Meaton, J. (2014). Driving corporate social responsibility in the malawian mining industry: a stakeholder perspective. Corporate Social Responsibility and Environmental Management, 21(4), 189-201.

Oberseder, M., Schlegelmilch, B. B., \& Murphy, P. E. (2013). CSR practices and consumer perceptions. Journal of Business Research, 66(10), 1839-1851.

Prud'homme, B., \& Raymond, L. (2013). Sustainable development practices in the hospitality industry: An empirical study of their impact on customer satisfaction and intentions. International Journal of Hospitality Management, 34, 116-126.

Rangan, V. K., Chu, M., \& Petkoski, D. (2011). Segmenting the base of the pyramid. Harvard Business Review, 89(6), 113-+.

Reimann, F., Ehrgott, M., Kaufmann, L., \& Carter, C. R. (2012). Local stakeholders and local legitimacy: MNEs' social strategies in emerging economies. Journal of International Management, 18(1), 1-17.

Sharma, A., \& Lee, M. D. P. (2012). Sustainable global enterprise: perspectives of stuart Hart, Ans Kolk, Sanjay Sharma, and Sandra Waddock. Journal of Management Inquiry, 21(2), 161-178.

Spence, L., \& Bourlakis, M. (2009). The evolution from corporate social responsibility to supply chain responsibility: the case of Waitrose. Supply Chain Management-an International Journal, 14(4), 291-302.

VanSandt, C. V., \& Sud, M. (2012). Poverty alleviation through partnerships: a road less travelled for business, governments, and entrepreneurs. Journal of Business Ethics, 110(3), 321-332.

Varsei, M., Soosay, C., Fahimnia, B., \& Sarkis, J. (2014). Framing sustainability performance of supply chains with multidimensional indicators. Supply Chain Management-an International Journal, 19(3), 242-257.

Viswanathan, M., \& Sridharan, S. (2012). Product development for the bop: insights on concept and prototype development from university-based student projects in India. Journal of Product Innovation Management, 29(1), 52-69.

Weidner, K. L., Rosa, J. A., \& Viswanathan, M. (2010). Marketing to subsistence consumers: Lessons from practice. Journal of Business Research, 63(6), 559-569.

Wolf, J. (2011). Sustainable supply chain management integration: a qualitative analysis of the German manufacturing industry. Journal of Business Ethics, 102(2), 221-235.

Wolf, J. (2013). Improving the sustainable development of firms: the role of employees. Business Strategy and the Environment, 22(2), 92-108.

Zeng, F., Li, J., Zhu, H., Cai, Z. Y., \& Li, P. C. (2013). How international firms conduct societal marketing in emerging markets. Management International Review, 53(6), 841-868. 